\title{
The Research on the Cultivation Mode of Applied Talents in Surveying and Mapping Engineering based on the Market Orientation
}

\author{
You yingchun \\ The Traffic Engineering College \\ of Shenyang Jianzhu University \\ Shenyang China \\ 171220963@qq.com
}

\author{
Ma Yuntao \\ The Traffic Engineering College \\ of Shenyang Jianzhu University \\ Shenyang China \\ 55603639@qq.com
}

\begin{abstract}
By using the professional geomatics engineering application type transformation pilot as the background, To solve the problem of imperfect knowledge system at present. This focus on cultivating students' practical ability, improve the level of theory and practice skills of students, cultivate students' innovation consciousness, the education and the market closely together, making curriculum system, scientific and feasible construction scheme, teachers practice construction scheme and a full range of professional training programs, establish complete training applied talents security mechanism and other measures. Deepen the practical ability of personnel training methods of practical talents, and promote the application of Surveying and mapping engineering to change.
\end{abstract}

Keywords-Higher education; surveying and mapping specialty; application type; training mode

\section{INTRODUCTION}

The situation that the difficult of college students find jobs and the company recruitment has become social common view. In 2015, The Ministry of education and other dependent departments jointly printed and distributed guidance opinion of guiding local undergraduate universities application type transformation [1]. General Office of Liaoning Provincial People's Government printed and distributed implementing opinion of promoting undergraduate universities application type transformation. National and local governments solve the problem of personnel training curriculum system, experiment practicing link and the teacher's knowledge structure and practical skills that are out of line with the market demand by a series of policies [2]. Geomatics Engineering is a strong comprehensiveness subject. The aim of professional geomatics engineering transformation pilot is training Innovative practical elite with guiding by market demand [3]. We should fundamentally improve the practical skills of college students from the ways of building teachers' team and curriculum system, strengthening application skills, increased cooperation between schools and enterprises, reforming assessment system and so on ${ }^{[4][5]}$

Education, teaching and research project of China Construction Education Association in 2017 (No. 2017077)

\section{THE PROBLEMS OF GEOMATICS ENGINEERING PROFESSIONAL TEACHING AT PRESENT STAGE}

How to update the educational thought of Geomatics Engineering professional teaching, training innovative talents to meet the needs of social development has become an urgent problem of University geodetic engineering specialized in personnel training process [6-7]. At this stage, the university geodetic engineering specialized mainly has following several problems:

\section{A. Courses system setting out of step with market demand}

In recent years, navigation, geographic information, digital photogrammetry, remote sensing and other technologies flourish that be applied more and more in the National economy.

\section{B. Emphasizing theory and neglecting practice.}

Practice ability cannot satisfy the request. Geomatics Engineering is a strong comprehensiveness subject. For much learning it is difficult to achieve ideal effect by teaching knowledge in theory in class [8]. However a number of university courses still focus on theoretical study and practice mainly for the moment. It lacks of co-operation between schools and enterprises. Moreover enterprises are seriously lack of understanding of cooperation education between school and enterprise. Some enterprises are short of involving enthusiasm and responsibility of cooperative culture. So that it is difficult to start comprehensive and effective in-depth school cooperation education.

\section{Lack of creativity}

Most teachers only simply complete the teaching task but they ignore the curiosity and imagination of the students [9]. Furthermore students are also used to solving practical problems passively and mechanically [10]. There is few students can ask questions actively. A minority number of student are short of courage and ability of analyzing and solving problems. 
Above all problems affect the education for students' ability in school and restrict the development of disciplines. It makes student employment situation negatively which need to be addressed.

\section{TRAIN THE APPLICATION TYPE TALENTS GUIDING SYSTEM BY MARKET DEMAND}

We want to solve the problem of incomplete Surveying and mapping engineering knowledge system by the ways of develop a scientific and feasible curriculum system, teaching staff construction program, practice program and an all-round professional training program base on Surveying and mapping engineering application talents system by market guidance research. Focusing on improving students' ability to transform theoretical knowledge into practical skills, and to improve the contact between education and the market, so as to improve the situation that the difficult of college student find jobs and the company recruitment.

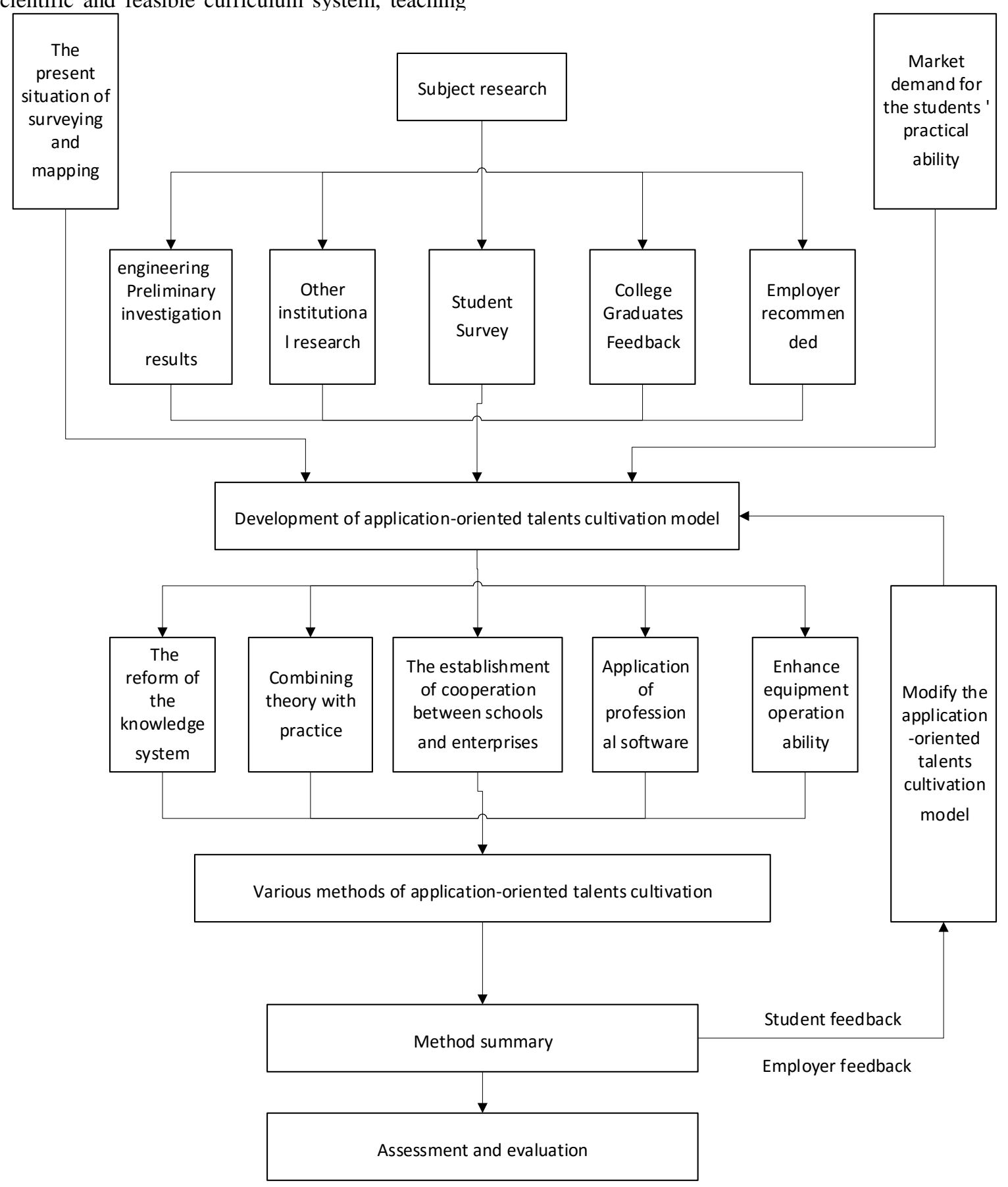

Fig. 1. Research ideas and methods 


\section{A. Building Surveying Engineering course system}

We suggest that add the mapping geographic information industry emerging technologies of geographic information engineering technology, geographic information system development, digital photogrammetry, and remote sensing image interpretation to course system. It can provide students with the latest knowledge and technology learning resources in the field of geographic information. In order to train high quality application talents that meet the current needs of Surveying and mapping Geographic Information Industry.

\section{B. Train double qualified teachers by cooperation between schools and enterprises}

At present, the school teachers are generally weak in practicing and not suitable for meeting the current demand of application type transformation. It is the basis of carrying out the application transformation pilot work in colleges to train double qualified teachers. As for improving the practical ability of college teachers and training double qualified teachers which have Both engineering practice and innovation spirit, teachers will be sent to the enterprise training and participate in the actual production projects by cooperation between schools and enterprises.

\section{Perfect the project of practicing linking}

The project of practicing linking should include the practice plan and the practice condition (laboratory equipment, laboratory, practice base).It also has practice links assessment system and so on. Practicing linking in Surveying and Mapping Engineering mainly includes course design and student practice.

(1) Course design includes technical course design of geographic information engineering and design of interpretation course for remote sensing images. Students should be in the skillful use of setting up a database by ARCGIS software as well as skilled use Remote sensing ENVI and ERDAS to processing remote sensing image.

(2) Student practice includes basic practice of Surveying and Mapping, digital mapping practice, control surveying practice, engineering surveying practice, GNSS principle and application practice, photogrammetry practice and so on. It is necessary to master the practical skills, but also learn to use the appropriate software that is the goal of the above practice. The mainly design software includes CASS digital mapping software, Family software, satellite navigation data processing software and digital photogrammetry Map Matrix software.

\section{Establish a completely guaranteed system for training practical elite}

The construction of mechanism is an important guarantee for the training of application type talents. It includes investigation mechanism by market demand (university survey, enterprise survey, graduate Survey), teacher evaluation system (peer evaluation, student evaluation, Graduate evaluation), equipment protection mechanism (instrument calibration, maintenance and update), building practice base mechanism, students practice link assessment mechanism.
The first stage, the current research and construction of the surveying and mapping engineering curriculum system, the construction of teaching staff, the practice of assessment and so on. At the same time, to the surveying and mapping students in the school to issue a questionnaire or discussion to understand the students on the current situation of teaching and mapping professional advice, as well as market-oriented mapping engineering application-oriented training model needs and recommendations. Extensively listen to the views and suggestions of graduates and employers to understand the market trends and the needs of employers in the application of students. The second stage, according to the research data to develop a detailed and practical "based on market-oriented mapping engineering application-oriented training model" program.

\section{CONCLUSION}

The innovation and development of education requires us that grasp the core of the times by starting from the market. It also asks us to cultivate the practical talents that society needs so as to promote education with the development by time going on. It puts forward the viable practical talents training mode that include preferring Surveying Engineering course system, improving students' professional knowledge and deepening talent practical ability training. In order to solve the problems of college students lack practical ability, education is out of line with industry development and talent cannot meet the market demand which promotes the pilot work of Surveying and Mapping Engineering transformation.

\section{REFERENCES}

[1] Dong chunlai,Jiao minglian,Zhou li. Research on New Practical Teaching System Based on Excellent Surveying and Mapping Engineer [J]. Mapping notification, 2013( 11) : 117-120(In Chinese).

[2] Yang keming,Shi gangjiang,Wei huafeng. Research information mapping skills training for employment demand model [J]. Higher Education in Coal,2014,32( 5) : 106-109(In Chinese).

[3] Ning dianmin . Discussion on Improving Teaching Quality of Surveying and Mapping Practice $[\mathrm{J}]$. China Metallurgical Education, 2013( S1) : 72-73(In Chinese).

[4] MA Hongjiao,HU Yonghui,YUAN Haibo,et al. Designand Analysis of Embedded GPS/D R Vehicle Integrated Navigation System[C] // International Conference on Embedded Software \& Systems Semposia. [S. 1]: IEEE,2008.

[5] He Liheng, Shi Yufeng, Zheng Jiazhu. Construction of Practical Teaching System for Undergraduate Course of Surveying and Mapping Engineering [J]. Bulletin of Surveying and Mapping, 2010 (8): 74-76. (In Chinese)

[6] Liu Jie.Study on the Reform of Teaching Mode in Colleges and Universities with the Goal of Improving the Employment Force [J]. Journal of Shanxi Colleges and Universities Social Sciences. 2008,20 (3): 124-126. (In Chinese)

[7] Jiao Ming Lian. Cooperative education of industry and learning. Training of innovative talents in surveying and mapping. Surveying and mapping engineering, 2011, 20 (1). (In Chinese)

[8] Lv Weicai, Zhang Ergang. A new model of Surveying and mapping applied engineering and technical personnel training. Surveying and mapping, geospatial information, 2013, 36 (9). (In Chinese)

[9] Wang Yanxia, Zheng Pingjian, et al. Discussion on the construction of Surveying and Mapping Practice Teaching System in applied universities. Mine surveying, 2010, (5). (In Chinese) 
[10] Ma Chunyan, Liang Cuiying, et al. Research on the practice teaching reform of "four-dimensional seepage" in surveying and mapping engineering. Surveying and mapping bulletin, 2013, (2). (In Chinese) 